\title{
5 \\ USING LIVES: THE AUSTRALIAN DICTIONARY OF BIOGRAPHY AND ITS RELATED CORPORA
}

\author{
MELANIE NOLAN
}

The Australian Dictionary of Biography $(A D B)$ is one of many biographical dictionary projects developing advanced biographical functions. The $A D B$ is the largest and longest-running project of national collaboration of social scientists in Australia, having started in the late 1950s. Over 4,500 authors have contributed to its 13,500 entries. In 2006 the $A D B$ made the cultural journey from a printed book to an online digital research resource. Since then staff have created companion biographical websites: Obituaries Australia, which reproduces published obituaries; and People Australia, which features other biographical material such as records from Who's Who and out-of-copyright compendiums of biography. People Australia also acts as a Biographical Register. These companion websites now give us the technical capacity to register all deceased Australians in our websites. Since 2011 we have also begun to comprehensively index all entries, which, in turn, allows us to automatically generate visualisation tools, such as family trees.

In my history of the $A D B, \mathrm{I}$ argued that three main activities have laid at the heart of the $A D B$ project since 1957: publishing books of concise entries, the Biographical Register, and indexes of entries. The $A D B$ 's core activities remain well-researched concise articles, a Biographical Register, 
and being able to navigate around both. ${ }^{1} \mathrm{~A}$ fundamental transformation of the project, however, has been concomitant with the digital redesign. We are now able to identify and add whole groups of 'missing persons', create bigger data and manipulate it-lump and split groups of articles for research purposes and link them to other digital resources. Prosaic matters constrain our ambitions: navigating new research infrastructure; trying to innovate while at the same time addressing our existing flaws; and honouring our national mission. In this chapter I discuss the extent to which our methodologies have been redesigned too. While we have an expanding set of digital activities, and are developing tools to generate advanced biographical research, we are still concerned with a couple of basic problems; namely, balancing representativeness and significance, and dealing with the tension between the few and the many. I will begin by discussing the practical problems: our resources, the need to observe the discipline of a dictionary, and, in light of both these matters, setting priorities.

\section{New Research Infrastructures to Meet Research and Funding Challenges}

Unlike a number of other biographical dictionary projects, the $A D B$ has a requirement to use the data we have developed, especially the indexing or fielding capacity, to develop biographical practice, to answer research questions, and to disseminate our material both freely and widely. This is a relatively new imperative but it builds on earlier practice. From the outset, the $A D B$ has been hosted in a university, The Australian National University (ANU). During this time it has been subject to a series of reviews. ${ }^{2}$ Most recently in 2007 Professor Bob Gregory chaired a working party to investigate the $A D B$ 's priorities and future directions. As a result of the Gregory Report, the $A D B$ was subsumed into a newly developed National Centre of Biography (NCB) in 2008. This restructuring was premised on the view that the $A D B$ should

1 Melanie Nolan, 'From Book to Digital Culture: Redesigning the $A D B$ ', in The ADB's Story, eds Melanie Nolan and Christine Fernon (Canberra: ANU E Press, 2013), 373-93. doi.org/10.22459/ ADBS.10.2013.12.

2 Melanie Nolan, “'Insufficiently Engineered”: A Dictionary Designed to Stand the Test of Time?', in Nolan and Fernon, The ADB's Story, 5-33. doi.org/10.22459/ADBS.10.2013.01. 
act as a focus for, and to develop proficiency in, the study and writing of biography in Australia; to coordinate the activities of biographers throughout the ANU; to conduct public lectures, seminars, symposia and other forms of academic and scholarly exchange in the field; to attract outstanding scholars on visiting scholarships and short-term appointments; to train the next generation of biographers through postgraduate and summer school programs; to produce new volumes of the $\mathrm{ADB}$ up to Volume 20; to continue to develop the ADB online; and to work more closely with, and conduct joint research and exhibitions with, the national cultural institutions. ${ }^{3}$

The $A D B$ was integrated into the School of History in 2010 to help realise these objectives. So, after half a century, the $A D B$ was tasked with a broader research program of connecting its research within wider biographical practice. Since 2008 the $A D B$ has progressively included a group of academic, as well as professional, staff, and it has been charged with developing a broader agenda appropriate to a biographical research centre which hosts a dictionary project.

At the same time, the $A D B$ is not a commercial endeavour but has imperatives to make its work freely accessible. This derives from its being a national collaboration that ANU brings together. The $A D B$ is made up of autonomous working parties in the states and territories. There are also some thematic working parties. Its design is organic and federal. Chairs and representatives of working parties are brought together in an editorial board, which advises the unit, or 'headquarters', at ANU. Membership of the editorial board has always been deliberately inclusive of a range of colleagues from across Australia. ANU has managed to construct a work of such complexity only by being a national collaboration. Remarkably, for over 50 years the editorial board - as well as working party members and contributors-have given their time freely to the project without payment.

Of course it has behoved ANU to host the $A D B$ on these terms. ANU was established in 1946 with a nation-building charter charging it to encourage and provide facilities for research and postgraduate study,

3 Darryl Bennet, 'The Di Langmore Era, and Going Online, 2002-2008', in Nolan and Fernon, The ADB's Story, 190-91. doi.org/10.22459/ADBS.10.2013.06, summarising R. G. Gregory, Tom Griffiths, Ann Curthoys, Linda Boterill, and Daniel Stoljar, 'Australian Dictionary of Biography Working Party Report to the Director', Research School of Social Sciences Review (2007), NCB/ ADB files, 1, ANU Archives, Canberra. 
especially in relation to subjects of national importance to Australia. ${ }^{4}$ Professor Keith Hancock took up the dictionary project in 1957 as part of his professorial leadership and to provide a rationale in terms of the history profession for ANU leadership. ${ }^{5}$ The $A D B$ has been funded under the national institutes 'block grant', now known as the National Institutes Grant. This is provided to ANU and three other higher education providers in recognition of the role they play in facilitating key activities that are of national significance. ${ }^{6}$ Furthermore, the $A D B$ was the recipient of Australian Research Council (ARC) funding, which, together with some endowment funds, underwrote its going online. ${ }^{7}$ It received the funding to extend the $A D B$ 's capacity and to render it a

key agent in the development of a national open-information network for research in the humanities and social sciences [in Australia]. In association with national cultural institutions, the project ... [was designed to] create sustainable links between information systems and $\ldots$ pioneer ground-breaking research capabilities. Setting new standards for accessibility and usability, it ... [was expected to] be a major driver in the development of a comprehensive network of digitised resources. ${ }^{8}$

As a consequence of its being a national collaboration funded by universitygenerated resources, the $A D B$ has been required to be accessible and usable. ANU is committed to disseminating the $A D B$ 's enriched data and tools as widely as possible and 'free to air'. As a consequence of its being free to air, the Dictionary's 9 million words, and increasingly enhanced research tools, attract over 60 million hits a year.

The $A D B$, moreover, is being enmeshed in a range of national digital infrastructures, which have been developed with public funds and, in turn, are also provided free to air: Trove and Humanities Networked

4 Hon. John Johnstone Dedman, MP, Minister for Post-War Reconstruction, 'Second Reading Speech-Australian National University Bill 1946', Hansard, 19 June 1946.

5 Melanie Nolan, 'Country and Kin Calling? Keith Hancock, the National Dictionary Collaboration, and the Promotion of Life Writing in Australia', in Clio's Lives: Biographies and Autobiographies of Historians, eds Doug Munro and John G. Reid (Canberra: ANU Press, 2017), 247-72. doi.org/10.22459/CL.10.2017.11.

6 The Australian National University, the Australian Maritime College (AMC), Batchelor Institute of Indigenous Tertiary Education (BIITE), and the Victorian College of the Arts at the University of Melbourne all receive funding under the National Institutes Program.

7 The $A D B$ used $\$ 300,000$ of its endowment together with three Australian Research Council, Linkage Infrastructure, Equipment \& Facilities (LIEF) Grants to go online in 2004-06: LE0452798 in 2004; LE0560774 in 2005; and LE0668026 in 2006.

8 ARC Final Report-Linkage-Infrastructure-LE0668026, B1, 2007. 
Infrastructure (HuNI). In 2009, the National Library of Australia created Trove, a free online database of Australian library resources, with a powerful search engine, which built on earlier catalogues. ${ }^{9}$ Included in that treasure trove of resources are digitised newspapers starting from the very first to have been published in Australia. Some of the newspapers go as far as the 1990s, though most stop at 1954. More than 1,000 Australian newspapers have so far been digitised. ${ }^{10}$ They include the major dailies, regional papers, religious newspapers, and trade papers. The $A D B$ and the NLA have signed a memorandum of agreement to share resources. ${ }^{11}$ As part of that agreement Trove is promoting $A D B$ and Obituaries Australia entries on its site. Trove is the Commonwealth's fourth most heavily used website with more than 55,000 visitors a day. ${ }^{12}$ In 2016 Trove was the recipient of funding from the Public Service Modernisation Fund to digitise material and upgrade its system.

Trove has been a fundamental part of the online development of the $A D B$. Its digitised newspapers contain hundreds of thousands of obituaries for us to mine for Obituaries Australia. So far the $A D B$ has selectively added 7,500 to Obituaries Australia. We are also enriching $A D B$ and Obituaries Australia entries by linking to references of the subjects in digitised newspapers. And the NCB's Digitisation Facility, which operated from 2010 to 2014, digitised over 250 out-of-copyright compendiums of biography, which will eventually be available to the public through the National Library's Trove search facility. ${ }^{13}$

The $A D B$ is part of another national consortium, HuNI, a project aimed at 'unlocking and uniting Australia's Cultural Data'. HuNI was federally funded through the National eResearch Collaboration Tools and

9 Catriona Bryce, 'Trove-A Brief History', National Library of Australia, 5 November 2014, accessed 12 August 2017, www.nla.gov.au/blogs/trove/2014/11/06/trove-a-brief-history.

10 The modestly funded Australian Newspapers Digitisation Program at the National Library of Australia estimates that a total of 7,700 newspaper titles have been published in Australia: 'Australian Newspaper Digitisation Program', accessed 30 July 2018, www.nla.gov.au/content/ newspaper-digitisation-program.

11 Memorandum of Understanding (MoU), contribution of data for Trove, signed by Debbie Campbell, Director, Collaborative Services, NLA (2 October 2012) and Melanie Nolan, Director, National Centre of Biography, and General Editor, Australian Dictionary of Biography, Research School of Social Sciences (26 September 2012), NCB/ADB Archives.

12 The most heavily used Australian websites are, in order: the Bureau of Meteorology, Centrelink, the Department of Human Services, and then Trove, the latter with more than 55,000 visitors a day. Australian Library and Information Association, submission in response to the Productivity Commission Data Availability and Use Issues Paper, 29 July 2016, accessed 30 July 2018, www.pc. gov.au/inquiries/completed/data-access/submissions.

13 Biography Footnotes, no. 14 (June 2015): 4. 
Resources (NeCTAR). The project involved building a virtual laboratory or network of digitised resources, providing a single 'federated' source for information on any significant Australian, with searches in turn being directed to linked resources in Australian and overseas collections. ${ }^{14}$ The government's investment in National Research Infrastructure for Australia has been made on the basis that it enhances the use of data, 'such as open access policies and provisions ... to encourage a collaborative, sustainable approach to research data and research data infrastructure in Australia'. ${ }^{15}$

Both the Trove and HuNI collaborations have been developed on the basis that the $A D B$ is freely accessible online in aid of national objectives. The $A D B$ 's research strategy and its accessibility is overdetermined then by its foundational culture which has been reinforced by the new research infrastructure it finds itself embedded in since it went online in 2006.

\section{Balancing Significance and Representation}

Although the $A D B$ has the ability to register all Australians in our websites, if it wanted to, it maintains the discipline of the dictionary to balance significance and representation. As Bill Oliver, the inaugural Dictionary of New Zealand Biography (DNZB) general editor, noted, a balance was needed between the 'unavoidable weight' of 'major figures' and 'a sizeable representation of those who were not in their lifetimes imposing presences, but who might, given the nurture of research and writing, become memorable historical presences'. ${ }^{16}$ National biographical dictionaries are uniquely positioned to play a critical role in larger historiographical conversations, in large part because of the sheer breadth and scope of their contents, but which are short of being all-inclusive.

14 NeCTAR, HuNI, CI Prof Melanie Nolan and Dr Paul Arthur Deakin Humanities Networked Infrastructure (NeCTAR) Fund No. S4430304 Aries ID 17825, CIs Paul Arthur and Melanie Nolan. 15 National Research Infrastructure for Australia, The Australian Research Data Infrastructure Strategy. The Data Revolution: Seizing the Opportunity, 2016. See the earlier National Collaborative Research Infrastructure Strategy (NCRIS), 2011 Strategic Roadmap for Australian Research Infrastructure.

16 W. H. Oliver, 'Introduction', in Dictionary of New Zealand Biography, ed. W. H. Oliver, vol. 1, 1769-1869 (Auckland: Auckland University Press, 1990), vii. This is similar to Sidney Lee's criteria: 'the probability that his (or her) career would be the subject of intelligent enquiry on the part of an appreciable number of people a generation or more hence'. Gillian Fenwick, Women and the Dictionary of National Biography: A Guide to DNB Volumes 1885-1985 and Missing Persons (Aldershot: Scolar Press, 1994), 21. 
In this regard, the $A D B$ might have an advantage over many other biographical dictionary projects. The criteria for inclusion in the Oxford Dictionary of National Biography from 1885 to now is 'people who have left their mark on an aspect of national life, worldwide, from the Romans to the early 21 st century'. ${ }^{17}$ Similarly, the inaugural editor of the Dictionary of American Biography in 1928, Allen Johnson, while noting that the word 'American' was fraught with ambiguities, followed the Dictionary of National Biography principle that 'only those who had made some significant contribution to American life' should be included. ${ }^{18}$ The $A D B$, however, has always been more inclusive. In April 1960, the national committee, the predecessor of the editorial board, agreed that the $A D B$ should reflect the federal and national character in its presentation, and 'give a representative picture of all strands of Australian life, observing the varying interests from state to state' ${ }^{19}$ The $A D B$ has prided itself on the inclusion of representative as well as significant people: since 1966, prefaces to volumes have noted that 'Many of the names were obviously significant and worthy of inclusion. Others, less notable, were chosen simply as samples of the Australian experience'. ${ }^{20}$ Douglas Pike, the inaugural general editor, noted about volume one that representatives 'of ethnic and social minorities and of a wider range of occupations, or as innovators, notorieties or eccentrics' had been included. ${ }^{21}$ Currently, the $A D B$ defines its scope as a 'blend of elitism and egalitarianism. As well as selecting individuals who have made a prominent contribution to the Australian nation for inclusion in the ADB' an attempt is made 'to reflect the rich variety of Australian life by including representatives of every social group and sphere of endeavour'. ${ }^{22}$ Such a flexible, pragmatic, and

17 'Frequently Asked Questions', Oxford Dictionary of National Biography, accessed 8 January 2017, global.oup.com/oxforddnb/info/faqs/.

18 Allen Johnson, 'Introduction', Dictionary of American Biography, ed. Allen Johnson, vol. 1, Abbe-Barrymore (New York, Scribner, 1928), cited by Kristine J. Anderson, 'Dictionary of American Biography', in Encyclopedia of Life Writing: Autobiographical and Biographical Forms, ed. Margaretta Jolly, vol. 1, $A-K$ (Chicago: Fitzroy Dearborn Publishers, 2001), 271-72.

19 A. Mozley, 'The Australian Dictionary of Biography', Historical Studies: Australia and New Zealand 9, no. 35 (1960): 313-14.

20 Douglas Pike, 'Preface', Australian Dictionary of Biography, ed. Douglas Pike, vol. 1, 1788-1850, $A-H$ (Carlton, Vic.: Melbourne University Press, 1966), v. See also Gerald Walsh, 'Recording "the Australian Experience": Hancock and the Australian Dictionary of Biography', in Keith Hancock: The Legacies of an Historian, ed. D. A. Low (Melbourne: Melbourne University Press, 2001), 249-68.

21 Pike, 'Preface', v.

22 'Frequently Asked Questions: Who Determines Which Subjects Merit an Entry in the ADB?' Australian Dictionary of Biography, accessed 8 January 2017, adb.anu.edu.au/frequently-asked-questions \#determines. 
wide-ranging principle means that the $A D B$ can easily adapt to including groups previously underrepresented on class, race, gender, or sexuality grounds.

The $D N Z B$ followed the $A D B$ in seeking representativeness as well as significance. ${ }^{23}$ The former project began in 1983, with five volumes produced between 1990 and 2000. Compared to previous dictionaries, it was designed to 'provide a balance of individuals from across New Zealand society', especially to include women, Māori (non-Europeans), and other minority groups. ${ }^{24}$ The $D N Z B$ had the advantage of being designed and developed later than other projects. As Lawrence Jones noted, 'democratic in its inclusion and in its method of selection determinedly bicultural and non-sexist ... the project is very much the expression of the cultural aspirations of New Zealand of the 1980s and 1990s' ${ }^{25}$ However, as Jock Phillips discusses in his chapter in this volume, the Dictionary was in abeyance and its revival is minimalist.

I argue that the digital challenge presents the $A D B$ with little soulsearching or need for new principles or mission in terms of conceiving new groups of people to include in the $A D B$ over time. What we consider important social categories have changed over time. ${ }^{26}$ Challenging though the new digital environment is, we can fairly easily adapt to it because of ongoing concern with both significant and representative subjects. Accumulating bigger databases and developing longitudinal processing methods to use lives is compatible with our long-standing mission and concerns with the relationship between the few and many, biography and history. The dilemma for the $A D B$ is both more prosaic and democratic: the institutional and funding constraints to our ability to carry out our mission. The trick is to avoid replicating our current shortcomings in the process of developing data and allowing free public digital access to the new developments in a challenging financial environment.

23 Melanie Nolan, 'The Politics of Dictionaries of Biography in New Zealand', in After the Treaty: The Settler State, Race Relations and the Exercise of Power in Colonial New Zealand, eds Brad Patterson, Richard S. Hill, and Kathryn Patterson (Wellington: Steele Roberts Aotearoa, 2016), 40-61.

24 'How Are People Selected for Inclusion?', Dictionary of New Zealand Biography, accessed 30 July 2018, teara.govt.nz/en/dnzb. Contrast with 'Frequently Asked Questions: What Are the Criteria for Inclusion in the Oxford DNB?', accessed 8 January 2017, global.oup.com/oxforddnb/info/faqs/.

25 Lawrence Jones, 'Dictionary of New Zealand Biography', in Encyclopedia of Life Writing: Autobiographical and Biographical Forms, ed. Margaretta Jolly, vol. 1, A-K(Chicago: Fitzroy Dearborn Publishers, 2001), 274-75.

26 See Miles Fairburn, 'The Problem of Absent Social Categories', in Miles Fairburn, Social History: Problems, Strategies and Methods (Basingstoke, Hampshire: Macmillan Press, 1999), 13-38. doi.org/ 10.1007/978-1-349-27517-5. 
The principles and process of selection may not have changed but the people making the selections have adapted and these are related. The $A D B$ 's advisory groups, the editorial board and the working parties, have altered over time. There has been a periodic refreshing of its aims and, with it, membership. For instance, in 1977 it was decided that there needed to be a female member of the editorial board. Heather Radi was the first woman appointed. In 1985 the board was 'revamped', as Geoff Serle, then general editor, made clear, with some younger members, more women members, and people with twentieth-century interests': historians Ann Curthoys and Jill Roe together with Don Aitkin, a political scientist, were appointed. ${ }^{27}$

A new dynamic is implicit in recent years: the $A D B$ is beginning to revise its entries, especially its range of representation, as well as highlight the research potential of the $A D B$ and its companion sites; a changing editorial board membership is both facilitating and reflecting these developments. The First Three Fleets project with family tree constructions is showcasing the $A D B$ 's research potential, which I deal with in the next section. In terms of revisions, the $A D B$ would like to rewrite at least the earliest volumes, which were published 50 years ago when the study of Australian history was in its infancy. But where is the money to come from? We have not been able to find it so far. In the meantime, we have embarked on a program to at least ensure that all birth, death, and marriage details are correct in our earliest volumes (volumes one and two published in 1966 and 1967 respectively). This modest aim is proving to be a considerable undertaking by two former deputy general editors, Darryl Bennet and Chris Cunneen, who both joined the editorial board in 2011. As deputy general editors, they knew that most corrigenda related to the first two volumes. Two other revision projects have also been initiated by new editorial board members: an ARC-funded Indigenous Australian Dictionary of Biography project, which Shino Konishi discusses in another chapter in this collection, and a colonial women's project.

In 2015 the ANU vice chancellor, Professor Ian Young, appointed the first Indigenous members to the board, welcoming Konishi and Stephen Kinnane, as part of the ANU's commitment to its Reconciliation Action

27 Jill Roe, 'National Collaboration: The ADB Editorial Board and the Working Parties', in Nolan and Fernon, The ADB's Story, 278. doi.org/10.22459/ADBS.10.2013.09. 
Plan. ${ }^{28}$ In addition to Konishi and Kinnane, Odette Best, who has recently been appointed chair of the $A D B$ 's all-Indigenous working party, joined the editorial board at the beginning of 2017, as did Katerina Teaiwa, the chair of the $A D B$ s s new Oceania working party. ${ }^{29}$ The new 24-member editorial board is now virtually gender-balanced. Ten years ago, women comprised less than a third of the 17-member board, but the addition of Konishi, Best, Joy Damousi, Bridget Griffen-Foley, Catherine Kevin, Lenore Layman, Carolyn Rasmussen, and Teaiwa has transformed its advisory groups. They have initiated or supported projects on convicts, colonial women, and Indigenous Australians.

We are also widening our temporal span. A number of other historians are attempting to shift the historical focus from discovery and colonisation in $1788 . .^{30}$ The first two volumes of the $A D B$ covered the period 1788 to 1850 . The $A D B$ has recently commissioned articles on Mungo Man and Mungo Woman, the cremated remains of a family who lived 42,000 years ago around the shores of Lake Mungo in what is now south-west New South Wales. The articles will not be biographical in the usual sense. They will be ground-breaking entries for the $A D B$, the first to use sources such as bones. ${ }^{31}$ Furthermore we are able to manage these projects because we have $A D B$ academic staff who specialise in Aboriginal, women's, and family history, complementing editorial board members.

For instance, Konishi (University of Western Australia), Malcolm Allbrook (ANU), and Tom Griffiths (ANU), working closely with Kinnane (University of Notre Dame of Australia and ANU), successfully applied for an ARC Discovery (Indigenous) grant of \$732,704 over four years. They are all members of the $A D B$ editorial board with Griffiths being its chair and Allbrook the $A D B$ 's managing editor. The project will work closely with the $A D B$ 's Indigenous working party, which consists of over a dozen Indigenous scholars from around Australia.

28 The delegation to approve the appointment of editorial board members lies with the vice chancellor of ANU. The protocol for appointing members is for the $A D B$ 's general editor, in consultation with the chair of the editorial board, to come to an informal agreement over membership, and then for the general editor to formally recommend members to the vice chancellor who then extends the invitation in writing to a person to become a board member.

29 A previous Indigenous working party operated briefly from 2006 to 2009.

30 For example, Nick Brodie, 1787: The Lost Chapters of Australia's Beginning (Melbourne: Hardie Grant, 2016).

31 Malcolm Allbrook, 'Inscribed in Stone and Bone: Writing Ancient Australian Lives', unpublished paper to the 2015 Australian Historical Association Conference, 'Foundational Histories', Sydney, 6-9 July 2015. 
Similarly, membership changes in the Victorian working party (VWP) relate to the colonial women's project. There are 10 women to 565 men in volume one, and 11 women to 596 men in volume two in the $A D B$ covering the period 1788-1850. Even after the missing persons volume in 2005 , the number of women subjects in the $A D B$ who 'flourished' before 1901 is just 161, compared to 3,895 men (and of those women subjects, 28 had shared entries or were minor entries). By contrast, nearly a quarter of those in the period currently being commissioned (those who died between 1991 and 2000) are women. The proportion of colonial women is woeful by any measure. VWP members Damousi, Rasmussen, and Patricia Grimshaw, are working with the general editor to add a further 1,500 entries about women to the pre- 1900 period.

We now have the capacity to register many people and to tell their stories. There are limits nonetheless. Online users expect online information to be up to date. But we simply do not have the resources to keep updating entries when new information is discovered. We do make exceptions for prominent individuals, however. When Mary Mackillop was made the first Australian saint, an extra paragraph was added to her entry to include that information. We are addressing recent work on frontier violence and will need to consider sexual abusers and those who were abused in light of enquiries such as the recent royal commission into institutional child abuse. ${ }^{32}$ It is difficult to come up with a 'true' national biography, more difficult than one might imagine. While big data is a catch-cry today, a dictionary is not a complete who's who, a database of Australian elites, or an expanded telephone book. The discipline of a dictionary is constrained by the evidence, selections, and the need to be concise. The $A D B$ has always held that a true national biography needs to capture both significant and representative Australians' lives. It needs to provide a gallery of all the possibilities of being Australian, past and present-as far as our funding allows. The difficulty lies in the fact, however, that what is considered significant or representative changes over time, so national biographies have to be sustained, dynamic, and never-ending tasks and, at some point, revised.

One other way we are developing the relationship between significant and representative individuals is by way of families. Families do not simply favour success. To the contrary, family history includes failures and dead-

32 See, for instance, the ARC-funded 'Colonial Frontier Massacres in Eastern Australia 1788-', University of Newcastle, accessed 6 July 2017, c21ch.newcastle.edu.au/colonialmassacres/; Royal Commission into Institutional Responses to Child Sexual Abuse, 2013-17. 
ends. Family history over time can be used to interrogate typicality and representativeness, in a way that a biography or single case sometimes does not. It allows biographers 'to deal with ordinary life. ${ }^{33}$ The usefulness of family histories is the ability to show relation and range. As Alison Light suggests in her recent book Common People, '[t]racking all the members of a family over time unsettles assumptions'. ${ }^{34}$ The $A D B$ - and its companion websites - offers us the opportunity of creating 'big data' for families and mediating systematically between individuals, families, and broader developments. All of the biographical records gathered and visualisations or family trees developed are being made freely available to the public via the NCB's websites.

\section{Dealing with the Few and the Many}

As well as being concerned with revision and changing conceptions of representativeness, then, the $A D B$ is focused on adding value, by developing research tools, and ensuring that these are accessible. The innovation has the potential for making a vast array of links between people. As Philip Carter has noted:

with projects, such as Obituaries Australia, editors ... are creating opportunities to establish hitherto unknown connections from, in effect, the 'bottom up.' These, moreover, are connections that go well beyond what is possible via the existing metadata of the $A D B$ or the $O D N B$ - for example, by bringing people together with reference to places of shared activity other than educational institution or residence, or by tracing sets of interrelated people as they move through different stages of life, from school to university to army service, and so on. ${ }^{35}$

The Biographical Information Management System (BIMS), developed by the NCB, and used in all its websites, is a world first among national biographical dictionaries and gives us the ability to more fully describe and visualise the relationships between individuals, and between individuals and general 'things' such as places, properties, families,

33 Eric Homberger and John Charmley, 'Introduction', in The Troubled Face of Biography, eds Eric Homberger and John Charmley (Houndmills, Basingstoke, Hampshire: Macmillan, 1988), ix.

34 Alison Light, Common People: The History of an English Family (Fig Tree: London, 2014), 34.

35 Philip Carter, 'Opportunities for National Biography Online: The Oxford Dictionary of National Biography, 2005-2012', in Nolan and Fernon, The ADB's Story, 354. doi.org/10.22459/ADBS.10. 2013.11. 
awards, and military service. ${ }^{36}$ One recent relational project is about place. As a pilot project, we created an online map of Ludwig Leichhardt's journey of exploration from Moreton Bay to Port Essington. Users can read his digitised journal while tracing his trip via Google maps. ${ }^{37}$ Most importantly, indexing allows us to consider the associational lives of Australians. We are creating a comprehensive database or authority file of names of organisations, including workplaces, schools, and clubs, that will be freely available to the public and can be used by other website creators to facilitate linking between sites. Families, of course, represent another kind of associational life.

A recent project which involves indexing, family history, and associational lives is based on the first three fleets to arrive in Australia. We deliberately chose this project because one of the $A D B$ 's aims is to revise its early volumes, as discussed above. Adding new records to our database relating to this period will help us when the time comes to choose new entries and because many of these people are the parents, siblings, or children of people in the $A D B$. What we are doing is adding records in Obituaries Australia and People Australia for all the people-be they convict, crew, marine, or governor-who set off from England in the first three fleets to New South Wales between 1787 and 1791. As well as mapping the fortunes of the 'fleeters', we are adding records for their children and grandchildren who were born or settled in the colonies. The purpose of the study is to understand more about family life during the colonial period of New South Wales. What kind of society was transported to the colony? What impact did convictism have on a family's long-term prospects? What led to some families succeeding over the generations while others failed? We are also interested in investigating contact history. We have already registered a few marriages and partnerings between the Indigenous and settler populations. We will be naming any Indigenous massacres and skirmishes as events and indexing people known to have participated in them. We are also listing people's participation in other events, and their alliances to various causes and people. William Bligh, for

36 Leonore Davidoff and Catherine Hall, Family Fortunes: Men and Women of the English Middle Class 1780-1850 (Chicago: University of Chicago Press, 1987); Andrew Gritt, Family History in Lancashire: Issues and Approaches (Cambridge: Cambridge Scholars Press, 2009).

37 'Leichhardt Expedition from Moreton Bay to Port Essington, 1844-1845', Australian Dictionary of Biography, accessed November 2018, adb.anu.edu.au/entity/8843. See Christine Fernon, 'Exploring Australia', Biography Footnotes, no. 13 (July 2014): 12. 
example, was a very controversial figure in early Australian history. ${ }^{38} \mathrm{ADB}$ entries and obituaries about people of his time often state whether the person was for or against Bligh, so we are now recording people's stance towards him in the related entities field.

We confined our project to the first three fleets because we had to set some parameters to make the study achievable within our resource constraints and on the advice of historical demographers, who are working with us on the project. There has also been a great deal of biographical research on the first three fleets, in particular Mollie Gillen's The Founders of Australia: A Biographical Dictionary of the First Fleet and Michael Flynn's The Second Fleet: Britain's Grim Convict Armada of $1790 .{ }^{39}$ Begun in 1982 by Keith Johnson and Malcolm Sainty as the Australian Biographical and Genealogical Record (ABGR) - with John Wilson joining as honorary treasurervolunteer genealogists, historians, and contractors have been transcribing, indexing, and linking archival and biographical records of Australia’s penal colonies and immigration schemes in a not-for-profit project, which is now known as the Biographical Database of Australia (BDA). We estimate that we will be adding 100,000 new biographical records to our databases as a result of this project. It will be a significant national resource. As well we are creating visualisation tools, all of which are being made publicly available through our websites to analyse the data that is being collected.

Given that the $A D B$ is a national project, the nation's foundational culture is an obvious subject to research. What is our method here? It is national, digital, and new, but the issues the tools are addressing are long-standing in dictionary practice. Our techniques and practices are informed by British historian Lewis Namier, whose reputation rests on his innovative use of collective biography, what is known as prosopography, in the study of the eighteenth-century parliamentary system. Namier was against the view that there was continuing and inevitable victory of progress over reaction-that is, his was an anti-Whig interpretation of history. Here we need to distinguish between Namierism, Namier's historical method, and Namier's techniques.

38 A. G. L. Shaw, 'Bligh, William (1754-1817)', Australian Dictionary of Biography, National Centre of Biography, The Australian National University, adb.anu.edu.au/biography/bligh-william-1797/ text2037, published first in hardcopy 1966, accessed online 14 January 2017.

39 Mollie Gillen with appendices by Yvonne Browning, Michael Flynn, and Mollie Gillen, The Founders of Australia: A Biographical Dictionary of the First Fleet (Sydney: Library of Australian History, 1989); Michael Flynn, The Second Fleet: Britain's Grim Convict Armada of 1790 (Sydney: Library of Australian History, 1993). 
Namier's particular interpretations on the sociopolitical structure of England in the eighteenth century have been the subject of debate but do not need to concern us here. ${ }^{40}$ Herbert Butterfield and others were highly critical more generally of Namier's historical method. Butterfield argued that Namier's method 'atomized everything'. In other words, it broke down complex historical events to simple social categories. Namier offered structural explanations ignoring, Butterfield argued, the fact that the structure itself is the result of human choices and could be altered by human choices. Secondly, Butterfield argued that human action was inherently more complex than Namier's view suggested. Namier did not take into account the significance and diversity of history, and the role of an individual's professed ideas, beliefs, and principles. ${ }^{41}$ His critics accused Namier of 'taking the mind of out of history', owing to his dislike of abstract political theory and his belief that much of human behaviour is 'senseless and irrational'.42

Be that as it may, Namier's techniques are more enduring and applicable here. Namier's was

a fabulously microscopic examination of the composition of the successive Houses of Commons under George III: where did the M.P.'s [Members of Parliament] come from, what was their family background, into what families did they marry, what and how much did they own, what was their education, what schools had they attended, who were their friends, what prompted one or the other to take up politics and stand for Parliament, in what ways did each one get elected? ${ }^{43}$

40 L. B. Namier, The Structure of Politics at the Accession of George III (London: Macmillan, 1929). See, for instance, reviews by Richard Lodge, History 14 (1929-1930): 269-70; D. A. Winstanley, English Historical Review 44, no. 176 (1929): 657-60. doi.org/10.1093/ehr/XLIV.CLXXVI.657; A. L. Cross, Journal of Modern History 1, no. 3 (1929): 473-77; and Times Literary Supplement, 31 January 1929, 69-70.

41 Herbert Butterfield, George III and the Historians (London: Collins, 1957), 299. See discussion, Kenneth B. McIntyre, Herbert Butterfield: History, Providence, and Skeptical Politics (Wilmington, DE: Intercollegiate Studies Institute, 2014).

42 John Brooke, 'Namier and Namierism', History and Theory 3, no. 3 (1964): 331-47. doi.org/ 10.2307/2504236. See also John Brooke, 'Namier, Lewis Bernstein, Sir, 1888-1960', in Makers of Modern Culture, ed. Justin Wintle (London and New York: Routledge, 2002), 380; and Lucy S. Sutherland, 'Sir Lewis Namier, 1888-1960', Proceedings of the British Academy, 1961 (London: British Academy, 1963): 371-85.

43 J. L. Talmon, 'The Ordeal of Sir Lewis Namier: The Man, the Historian, the Jew', Commentary, 1 March 1962, 237-46, accessed 30 July 2018, www.commentarymagazine.com/articles/the-ordealof-sir-lewis-namier-the-man-the-historian-the-jew/. 
His method was based on the study of biographies of members of parliament and their constituencies and the way they worked together, and was illuminated by careful research and psychological insight. He believed in a psychoanalytical interpretation of character, upbringing, temperament, and interests. He even went so far as to consult graphologists about the handwriting of an obscure eighteenth-century squire, and he would discuss the utterances, the lapses, and the style of a Hanoverian politician with a psychoanalyst. ${ }^{44}$ His focus was to ask questions about families, associational lives, and motivation. It proves applicable to other periods of history.

Namier's technique, like that of Ronald Syme and other prosopographers, was to study individual lives in minute detail before attempting any wider synthesis. ${ }^{45}$ His method was prosopography, or the use of biography to explore the connections and minutiae of networks systematically, for he 'believed that in order to understand an institution or a society "it must be broken up into its component parts, and these studied in isolation and then in relation to the whole"'. ${ }^{46}$ There were thus two parts to his technique. ${ }^{47}$ As Linda Colley makes clear in her 1989 biography of Namier, he was committed both to the 'intensely detailed' but also to 'penetrating analysis'. ${ }^{48}$ She goes further and suggests he really did not do as much as he meant to on the latter. He spent the last decade of his life producing three volumes of the History of Parliament: The House of Commons 1754-1790, which was made up of 2,000 biographies that he wrote himself by working nine hours a day in the basement of London's Institute of Historical Research, with three full-time assistants, which

44 Lewis Namier, 'History-Its Subject-Matter and Tasks', History Today 2, issue 3 (March 1952): $157-62$.

45 K. S. B. Keats-Rohan, ed., Prosopography Approaches and Applications: A Handbook (Oxford: P \& G, 2007); Lawrence Stone, 'Prosopography', Daedalus 100, no. 1 (1971): 46-79; Paul Magdalino, 'Prosopography and Byzantine Identity', in Fifty Years of Prosopography: The Later Roman Empire, Byzantium and Beyond, ed. A. Cameron (Oxford and New York: Oxford University Press, 2003): 41-56. doi.org/10.5871/bacad/9780197262924.003.0004; Jean-Michel Carrié, 'The Contribution of Papyri to the Prosopography of the Ancient World: Evaluation and Prospects', in Fifty Years of Prosopography: The Later Roman Empire, Byzantium and Beyond, ed. A Cameron (Oxford and New York, 2003), 92. doi.org/10.5871/bacad/9780197262924.003.0006.

46 W. N. Medlicott, 'Contemporary History in Biography', Journal of Contemporary History 7 , no. 1-2 (January-April 1972): 91. doi.org/10.1177/002200947200700105, quoting E. T. Williams and Helen Palmer, eds, Dictionary of National Biography, supplement, 1951-1960 (Oxford: Oxford University Press, 1971).

47 See E. A. Smith, 'Sir Lewis Namier and British Eighteenth Century History', Parliamentary Affairs 17, no. 4 (May 1964): 465-69.

48 Linda Colley, Lewis Namier (London: Weidenfeld and Nicolson, 1989). 
the History of Parliament Trust funded, as well as volunteers. ${ }^{49}$ By July 1960 all but 70 of the biographies were complete, and he began to plan a magisterial survey of his investigations in which he would set down his final version of eighteenth-century Britain. ${ }^{50}$ When he died just one month later, not a word had been written. ${ }^{51}$

Namier saw the possibilities of considering political motivations in terms of the schools, clubs, religious, and business and trade union affiliations of members of as well as their occupations, nationality, marriages, and kinship. In theory he was not excessively preoccupied by the individual at the expense of social collectivities and context. His thorough, indeed massive, research techniques called for cooperative work on a bigger scale than Namier managed. This is clearly core dictionary business.

For the $A D B$ is also only a potential piece of social research. Like Namier, we have been concentrating on accumulation, but we have had one eye on how we use the data to write political and social history. We made a start on the analysis with elite history. ${ }^{52}$ The biographical registers of members of the various Australian parliaments were an offshoot of the original $A D B$ biographical register. ${ }^{53}$ The series of alphabetically arranged biographies, with collective biographical introductions, relating to the

49 David Cannadine, 'The History of Parliament: Past, Present-and Future?', Parliamentary History 26, no. 3 (2007): 366-86. doi.org/10.1353/pah.2007.0052.

50 The three volumes of the History of Parliament: The House of Commons 1754-1790 were published posthumously in 1964 .

51 Colley, Lewis Namier, 72.

52 Richard Harrison argues that, despite being selective, the $A D B$ 's coverage of elites is quite high: 58 per cent of members of the Commonwealth Parliament; 42 per cent of members of the Victorian Parliament; 29 per cent of members of the Western Australian Parliament; 55 per cent of judges of superior and intermediate courts; 83 per cent of professors at the University of Melbourne; and 55 per cent of brigadiers (and equivalent) and higher ranks in the defence force. Harrison is currently compiling a broad-based register that will include members of all Australian parliaments and the judiciary in a single source. See Richard Harrison, 'Database of Australian Elites', Biography Footnotes, no. 10 (2010): 8-9.

53 A. W. Martin and P. Wardle, Members of the Legislative Assembly of New South Wales, 1856-1901, Social Science Monograph no. 16 (Canberra: The Australian National University, 1959); G. C. Bolton and Ann Mozley, The Western Australian Legislature, 1870-1930 (Canberra: Australian National University Press, 1961); D. B. Waterson, A Biographical Register of the Queensland Parliament: 1860 1929 (Canberra: Australian National University Press, 1972); Kathleen Thomson and Geoffrey Serle, A Biographical Register of the Victorian Legislature 1859-1900 (Canberra: Australian National University Press, 1972); Joan Rydon, A Biographical Register of the Commonwealth Parliament, 1901-1972 (Canberra: Australian National University Press, 1975); Heather Radi, Peter Spearritt, and Elizabeth Hinton, Biographical Register of the NSW Parliament, 1901-1970 (Canberra: Australian National University Press, 1979); Scott Bennett and Barbara Bennett, Biographical Register of the Tasmanian Parliament 1851-1960 (Canberra: Australian National University Press, 1980); D. B. Waterson and John Arnold, Biographical Register of the Queensland Parliament 1930-1980 with an Outline Atlas of Queensland Electorates 1859-1980 (Canberra: Australian National University Press, 1982). 
members of the Australian legislatures became, at the time, 'essential for research in Australian political history'. ${ }^{54}$ Allan Martin and Patience Wardle published the first, a register of members of the New South Wales Legislative Assembly, in 1959. By 1961 it had been decided to produce a continuing series of registers for each state and for the federal legislatures, entitled 'Australian Parliaments: Biographical Notes'. ${ }^{55}$

There has been a trickle of other collective accounts of $A D B$ articles. Bernard Smith and others at the Power Institute undertook a Biographical Dictionary of Artists and Architects with which the $A D B$ was involved although it was light on analysis. ${ }^{56}$ More directly related to $A D B$ work, The Makers of Australian Sporting Traditions (1993, edited by Michael McKernan) and The Diggers (1993, edited by Chris Coulthard-Clark [now Clark]) were special editions of selected entries from the $A D B .^{57}$ They were envisaged as the first of a 'proposed series of illustrated compilations from the A.D.B. on specialist subject areas designed to reach new readers and expose the A.D.B. to a wider audience', but the series never eventuated. ${ }^{58}$ One of the most systematic analyses was R. S. Neale's attempt to measure whether social mobility in the colonies was responsible for taking some of the 'sting out of the nineteenth-century radical movement' by analysing the social origins and characteristics of executive and administrative leaders in Australia from 1788 to 1856 who had entries in the first three volumes of the $A D B .^{59}$

54 C. N. Connolly, Biographical Register, NSW Parliament 1850-1901 (Canberra: Australian National University Press, 1983).

55 Connolly, Biographical Register, ix. See also C. N. Connolly, Biographical Register, NSW Parliament 1850-1901 (Canberra: Australian National University Press, 1983); C. N. Connolly, 'Politics, Ideology and the New South Wales Legislative Council, 1856-72' (PhD thesis, The Australian National University, 1975).

56 Nolan and Fernon, The ADB's Story, 31. Later development under Joan Kerr's leadership was taken further with the Dictionary of Australian Artists Online (DAAO) from 2004 and the Design \& Art Australia Online (DAAO) from 2010. 'History', Design \& Art Australia Online, accessed 30 July 2018, www.daao.org.au/history/.

57 Chris Coulthard-Clark, sel. and ed., The Diggers: Makers of the Australian Military TraditionLives from the Australian Dictionary of Biography (Carlton, Vic.: Melbourne University Press, 1993); Michael McKernan, sel. and ed., The Makers of Australia's Sporting Traditions: Lives from the Australian Dictionary of Biography (Carlton, Vic.: Melbourne University Press, 1993). A third, 'Colonial Australians', edited by Deirdre Morris and Geoff Browne, did not appear. Later and separately came G. P. Gilbert, ed., Australian Naval Personalities: Lives from the Australian Dictionary of Biography (Canberra: Sea Power Centre-Australia, 2006).

58 Research School of Social Sciences, Annual Report (1993), 68, box 137, Q31, Australian Dictionary of Biography Archives, The Australian National University Archives.

59 R. S. Neale, 'The Colonies and Social Mobility: Governors and Executive Councillors in Australia, 1788-1856', in Class and Ideology in the Nineteenth Century, ed. R. S. Neale (London: Routledge and Kegan Paul, 1972), 97-120. 
Now that we are developing bigger data, we require a '[p]rolonged collaborative effort and funding on a large scale' to use the data to ask and answer significant social history questions. ${ }^{60}$ We are not concerned merely with elites. ${ }^{61}$ In many ways, we are merely updating our methods of relating the few and the many, rather than the basic historical inclination to do so. 'Bricks are important' pronounced historian E. H. Carr in critical comments he made about Namier's work on the biographies of eighteenth-century members of the House of Commons, 'but a pile of bricks is not a house. And should the master-builder spend his time in a brick field?', seemingly unaware that Namier always intended to do both. ${ }^{62}$ So did the $A D B$.

\section{Conclusion: Something Old, Something Borrowed, Something New}

The wider biographical turn in history is propitious but the $A D B$ needs no new principles and policies to adapt to the digital age. ${ }^{63}$ Cost, national funding, intellectual property, and ethics are obvious major issues involved in producing innovative national biographical dictionaries in the digital age. More fundamental and less obvious are the issues of ensuring the 'shortcomings' of the existing $A D B$ are not magnified as we set out to employ bigger data and use lives as well as compile them. The $A D B$ 's advantages lie in its existing principles and policies. It is a national collaborative project, which is freely available online. Its selection criteria emphasises both significant and representative subjects. The greatest challenge is old-fashioned: practising what it has always preached. We are enthusiastically embracing the digital environment, as far as our resources allow, for it is facilitating our 'old-fashioned' mission.

60 Colley, Lewis Namier, 75.

61 Colley argues that Namier was 'fascinated by the sociology of elites, and by the intrigues and conflict that took place between men in high office'. He was not even much interested in how such men used the power they achieved. But he himself'deliberately chose to concentrate on biographies of MPs who were second- or even third-rate, or who were eccentric, or rogues, or in some cases insane'. She concludes that Namier, a conservative historian, was committed in the parliamentary biographies to an 'almost Marxian analysis of society and to the delineation of change'. Colley, Lewis Namier, 82. 62 E. H. Carr, 'English History's Towering Outsider', Times Literary Supplement, 21 May 1957, 577-78.

63 Prue Chamberlayne, Joanna Bornat, and Tom Wengrab, eds, The Turn to Biographical Method in Social Science (London: Routledge, 2000). 
This text is taken from 'True Biographies of Nations?': The Cultural Journeys of Dictionaries of National Biography, edited by Karen Fox, published 2019 by ANU Press, The Australian National University, Canberra, Australia.

doi.org/10.22459/TBN.2019.05 